\title{
Dual Innovation Performance through Knowledge-Based Network Structure: Evidence from Electronic Information Industry
}

\author{
Hao Jia-Jia', Li Chunling², Yuan Runsen ${ }^{3}$, Khansa Pervaiz ${ }^{4}$, Muhammad Asif Khan ${ }^{*}$, Sun \\ Xiaoran 6
}

${ }^{1,2,3,4}$ School of Economics and Management, Yanshan University

Qinhuangdao 066004, China

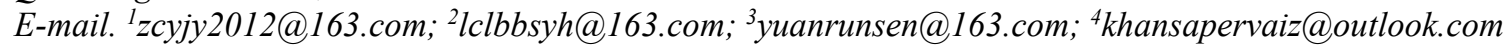

$5,{ }^{*}$ Faculty of Management Sciences, University of Kotil, Azad Jammu and Kashmir

City Kotli, 11100, Pakistan

Department of Business Management, University of Johannesburg

PO Box 524, Auckland Park, 2006, South Africa

E-mail.khanasif82@uokajk.edu.pk; *Correspondence:khanasif82@uokajk.edu.pk

${ }^{6}$ Business School, University of Leeds

Leeds, LS2 9JT, United Kingdom

E-mail.ml18x24s@leeds.ac.uk

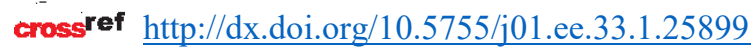

This study analyzes how knowledge-based network affects the dual innovation performance. Dual innovation includes exploratory and exploitative innovation, and knowledge-based network represents the relationships among knowledge-based elements. We take 269 enterprises having gone public in Shanghai and Shenzhen stock markets of the electronic information industry of China as samples and get the patent data for 5 years from 2014 to 2018. We consider building the knowledgebased network structure based on social network analysis method, and measure three features of the knowledge-based network, that are density, centralization and structure hole. We test the relationship between three network features and dual innovation performance through negative binomial regression method. The results indicate that there is an inverted U-Curve relationship between density and exploitative innovation performance. There is an inverted U-curve relationship between centralization and exploratory innovation performance. There is an inverted U-curve connection between the structure hole and the dual innovation performance.

Keywords: Knowledge-Based Network; Density; Centralization; Structure Hole; Exploitative Innovation; Exploratory Innovation.

\section{Introduction}

As the contradiction between resource environment and economic development is increasing prominently, people gradually realize that ecological carrying capacity has become the endogenous variable and rigid constraint condition of sustainable economic development. With the rapid development of manufacturing technology, the uncertain market environment and excessive ecological pressure force enterprises to carry out technological innovation. Innovation is the foundation of industrial development, so the purpose of innovation is to use less resources to create more performance.

Global externalization can be an effective approach to acquire access to worldwide knowledge. Nowadays manufacturing industry technology is developing rapidly and the uncertain market environment forces enterprises to carry out technological innovation. The "dualism" points out that under this scenario, the enterprise must take into account multiple activities at the same time (Gibson \& Birkinshaw, 2004). In the process of technological innovation, manufacturing enterprises face the contradiction of developing new technologies or utilizing existing technologies. If enterprises cannot weigh the development and utilization of new and old technologies better, it is difficult to achieve performance goals (Fan \& Liu, 2014). This is consistent with the "dualism" in organizational management. Enterprise knowledge base is the premise of technological innovation activities.

Knowledge-based theory states that new knowledge can be generated through the utilization and recombination of the accumulated stock of knowledge to form new technologies. This is the process of technological innovation. Knowledge is an important resource for enterprise development and has an important impact on enterprise technological innovation. Knowledge base theory defines knowledge base as the combination of R\&D investment and human capital, but more and more research is beginning to pay attention to the internal structure of knowledge-based elements. Modern technological innovation theory emphasizes the importance of knowledge structure, that is, in the process of technological innovation of enterprises, the importance of knowledge-based structure far exceeds the importance of knowledge-based element itself.

The knowledge-based structure reflects the enterprise's use of resources, the enterprise's existing core technology, 
enterprise's organization structure and production process. By optimizing the enterprise's knowledge-based structure, it can improve the efficiency of knowledge reorganization, create new knowledge, and ultimately improve the dual innovation performance. Knowledge-based network is the product of the integration of knowledge-based theory and modern technological innovation theory. Therefore, the knowledge-based network not only emphasizes the importance of knowledge-based elements, but also includes the importance of knowledge architecture.

Therefore, this article studies the relationship between the knowledge-based network and the dual innovation performance so that it can clarify how enterprises use the knowledge-based elements to carry out technological innovation and can also discover the effect path of the enterprise knowledge-based structure on the dual innovation performance. The study can provide purposeful and effective reference and method to improve enterprise innovation performance scientifically.

Firstly, we define enterprise exploratory and exploitative innovation performance intuitively using invention patents. Secondly, through the social network analysis method we construct the enterprise knowledgebased network structure using the industrial patent data and visualize it. We analyze the relationship between network density, centralization, structural hole, exploitative innovation, and exploratory innovation. Finally, we summarize the suggestions of improving knowledge management efficiency and improving enterprise dual innovation performance from the perspective of optimizing knowledge-based network.

\section{Literature Review and Hypothesis}

\section{Knowledge Base and Dual Innovation}

According to the development and utilization of new and old technologies the technological innovation activities of enterprises are divided into exploratory innovation and exploitative innovation. The two sides are called dual innovation which is contradictory parties that need to be weighed by innovation management. The exploitative innovation refers to the enterprise to conduct more in-depth mining based on current knowledge. The purpose is to make the existing technology more useful. The exploratory innovation means the process through which enterprises break the limit of the stock knowledge and increase the types of knowledge to acquire new knowledge and apply it successfully (Guan \& Liu, 2016). To conduct exploitative innovation the different ways of acquiring knowledge, enterprises takes the fully advantage of original knowledge, reduce innovation costs, reduce innovation risks and at the same time improve the competitive advantage in the original technology fields and markets. The result is an increase the economic benefits of enterprises. When enterprises engage in exploratory innovation, they start to enter other technical fields as well and need to find new breakthroughs in technology. It will increase innovation costs and risks but at the same time it will also get rid of the dependence on the original technology trajectory and help enterprises explore new ways. Its core competitiveness makes it a new economic growth pole (Garcia-Vega, 2006). Therefore, dual innovation has an essential supporting role for the sustainable development of enterprises and improving the dual innovation performance of enterprises has become the development direction of enterprise technological innovation.

The theory of modern technological innovation believes that knowledge architecture is more important than knowledge component (Henderson \& Cockburn, 1996; Henderson \& Cockburn, 1994). In the process of technological innovation, the importance of knowledgebased elements is far less important than the inherent relationship formed between knowledge-based elements. Because the intrinsic relationship formed between the knowledge-based elements can reflect the reorganization and exploit of knowledge in the process of technological innovation which reflects the technological innovation path of enterprises. The coupling degree between enterprise innovation strategy and knowledge structure is positively related to enterprise innovation performance. When enterprise knowledge structure is in the state of high element and low structure, enterprises should adopt exploitative innovation strategy. On the other hand, when enterprise knowledge structure is in low element and high structure, enterprises should adopt an exploratory innovation strategy (Yao \& Li, 2014). With regard to knowledge management, scholars have used bibliometric methods to analyze the knowledge structure and its evolution process of exploratory and exploitative innovation (Jia, Wang \& Cao, 2019; Liu, Lu \& Mei, 2018). Scholars have analyzed the evolution of the characteristics of knowledge structure from the perspective of patents (Xu, Z \& Chen, 2019). Technological innovation relies on knowledge search, both the breadth and depth of knowledge have a positive impact on internal knowledge search. At the same time structural holes can promote this positive effect (Wang et al., 2019). Excessive knowledge search depth will have a negative effect on the innovation performance, but the width of the knowledge base will buffer this negative effect. Excessive knowledge search will have a negative effect on the innovation performance of the enterprise and at the same time the width of the knowledge base will increase this negative effect.

\section{Knowledge-Based Network Structure and Innovation Performance}

Of course, knowledge management is important but the impact of knowledge-based structure on corporate innovation performance cannot be ignored. Some scholars have studied how the knowledge-based scale and knowledge-based characteristics can improve innovation performance (Colombelli, 2014; Dibiaggio, Nasiriyar \& Nesta, 2014; Wang et al., 2014). Enterprise network centrality positively affects new product development performance through knowledge width and knowledge depth; structure holes positively affect new product development performance through knowledge width (Chen $\&$ Zeng, 2019). In the context of technology mergers and acquisitions, there is an inverted U-shaped relationship between the similarity of knowledge structure and corporate innovation performance. There is also an inverted U-shaped relationship between the complementary of knowledge structure and corporate innovation performance (Mao, Shi 
\& Chen, 2019). The network centrality and network scale can improve the efficiency of external knowledge acquisition and knowledge transfer along with the network diversity promotes the efficiency of external knowledge acquisition (Zhan, 2019).

The complex knowledge-based network structure represents the complex process of enterprise knowledge integration. Enterprises can create more new knowledge to improve corporate innovation performance (Guan \& Liu, 2016). There is an inverted U-shaped relationship between the aggregation of the knowledge-based elements that constitute the knowledge-based network and innovation performance (Yayavaram, Srivastava \& Sarkar, 2018). Knowledge-based network can play a role as a structural coupling between countries and countries, which can promote the coupling between knowledge and the market. The degree of coupling depends on the innovation model and geographic scale of the knowledge-based network Tsouri, Hanson \& Normann, 2021). The goal of knowledge management is to establish a regional knowledge-based network to achieve regional sustainable development (Shahraki, 2019). Knowledge-based network as a policy mechanism plays an important role in the growth of regional knowledge (van Aswegen \& Retief, 2020). The average path length and agglomeration coefficient of the industryuniversity-research cooperation network have an important impact on c innovation, and the width of the knowledge base has a moderating effect on the relationship between the two (Yi \& Junhui, 2017). The threshold effect of four knowledge acquisition methods on innovation under the depth and breadth of the knowledge base. It proves that the depth and breadth of knowledge base have a threshold effect in the influence of knowledge acquisition on innovation performance (Zibiao, Keyuan \& Jingjing, 2021). The structure hole of the industry-university-research cooperation network has an important influence on the dualistic innovation of enterprises, and the knowledge base has a moderating effect in it (Junhui \& Yi, 2020). The density of the knowledge-base network has a negative effect on the company becoming a key developer. The knowledge-based network centralization presents a U-shaped relationship, while the disaggregation presents a positive correlation. Knowledge integration ability has an intermediary effect in the influence of knowledge-based network density and centralization on enterprises becoming key developers (Yan, Hong \& Cong, 2020).

The impact of both knowledge management and knowledge-based structure on innovation performance is directly or indirectly affected by the knowledge-based structure. Therefore, exploring the impact of the knowledgebased structure on the innovation performance has become a hot topic. However, the nature of the knowledge-based individual network cannot reflect the overall structure of the knowledge-based network. At the same time, enterprises that implement different innovation development strategies use knowledge differently. The domain to which the enterprise's knowledge base belongs has a great influence whether the enterprise conducts exploratory innovation or utilization innovation.

\section{Knowledge-based Network Density and Dual Innovation Performance}

In social network, the relationship among individuals can be explained by network characteristics (Scott, 1988). Network density is one of the important attributes of social network which refers to the close connection among the points of the network diagram. As the connection increases of fixed-scale network, the connections between nodes become closer and the network density also become higher. The actions and attitudes of nodes are largely influenced by other nodes that is; the greater the density of the network the more similar the characteristics of the nodes and stronger the consistency of the nodes (Scott, 2016) .

Knowledge-based network density refers to the correlation among knowledge elements in the process of technological innovation. The greater the density of the knowledge-based network, the richer the experience accumulated by the enterprise on the basis of existing knowledge as well as stronger the enterprise's confidence in recombining knowledge for exploitative innovation. In addition, the greater the density of the knowledge-based network of the enterprise, the more in-depth the enterprise can know the relationship between the elements. The outcome is better grasp of the market demand for exploitative innovation resulting from the recombination of knowledge which can improve the exploitative innovation performance and create value faster (Scott, 2016). However, when the density of the knowledge-based network exceeds a certain value, the greater the similarity between the knowledge the less likely it is that enterprises will generate new technologies through recombination of the knowledge base. The exploitative innovation performance will decline, and the enterprise will fall into the "technology dependence" predicament.

When the density of the enterprise knowledge-based network is small, the enterprise's technological innovation capability is insufficient. In turn, the exploratory innovation performance is low. Increasing the density of the knowledge-based network can promote enterprises to overcome the limitation of knowledge deficiency to carry out exploratory innovation and increase the variety of technologies. However, when the density of the knowledgebased network structure exceeds a certain value, it indicates that the existing technologies of the enterprise are highly correlated and the existing product market of the enterprise is relatively mature. The enterprise is unwilling to increase costs and enter new technology fields. Performance of exploratory innovation performance declined.

Based on the above analysis, the following hypotheses are proposed:

Hypothesis (1a): There is an inverted U-Curve relationship between the density of enterprise knowledgebased network and exploitative innovation performance.

Hypothesis (1b): There is an inverted U-Curve relationship between the density of enterprise knowledgebased network and exploratory innovation performance. 


\section{Knowledge-based Network Centralization and Dual Innovation Performance}

The centralization is another important indicator to describe the social network. It refers to the degree to which the network structure is built around a certain point or points (Miller, 2002). If the centralization of the network structure is larger it indicates that the social relationship of the graph is formed around one or several subjects. For example, the organizational structure of an organization is formed around departmental leaders. The central character will exist in a small group whose role is to connect scattered individuals if the central character in the small group withdraws, the group will disappear.

Centralization of knowledge-based network refers to whether the generation of new knowledge elements depends on one or some knowledge-based elements. When the enterprise's knowledge-based network structure has a central point, the enterprise has core technologies that can survive for a long time in a highly competitive market. Other technologies are based on core technologies and are extension of core technologies. When the enterprise's knowledge-based network structure does not have a central point, that is, when the knowledge-based network has a low centralization, the enterprise does not have core competitiveness, and the enterprise has a low degree of "technical dependence". Enterprise will not be limited by the initial investment in technological innovation, and it will have more energy and capital for exploitative innovation and exploration innovation.

However, as the market scope of the enterprise expands and business volume increases over time, enterprises begin to respond to fierce market competition. Currently, the centralization of the enterprise's knowledge-based network continues to increase beyond a certain range, and the enterprise focuses on the existing technology product market and has to reduce investment in exploitative innovation and exploration innovation. At this time, the dual innovation performance is reduced.

Based on the above analysis, the following hypotheses are proposed:

Hypothesis (2a): There is an inverted U-Curve relationship between the centralization of the enterprise knowledge-based network and the exploitative innovation performance.

Hypothesis (2b): There is an inverted U-Curve relationship between the centralization of the enterprise knowledge-based network and exploratory innovation performance.

\section{Knowledge-based Network Structure Hole and Dual Innovation Performance}

The well-known professor of sociology and strategy at the University of Chicago's School of Business Ronald Burt (1992) defined structural holes. He pointed out that the structural hole $(\mathrm{SH})$ is a buffer, which is equivalent to the insulator in the wire line. As a result, the benefits of the tworelationship people who have structural holes with each other contribute to the network can be accumulated but not overlapping (Burt, 1992). The essence of a structural hole is the non-repetitive relationship between two contacts.

The knowledge-based network structure hole refers to the hub-type knowledge node used by the enterprise in technological innovation. A hub-type knowledge node refers to the ability to spread radioactively in another technology area by breaking through one technology. When the structural hole is small, there are fewer network structure bridge nodes formed by the basic knowledge elements of the enterprise, and the technical fields to which the basic knowledge elements belong are similar, so whether the enterprise carries out exploitative innovation or exploration innovation, knowledge base can be absorbed and transformed well to create new knowledge and improve dual innovation performance; but with the increase of knowledge-based network structure hole, the distance between knowledge-based element increases and the similarity decreases. The infinite increase of structure holes results in each knowledge-based element becoming isolated node, there is no connection between nodes, and the cost and risk of enterprises carrying out exploitative innovation and exploratory innovation have greatly increased, which leads to a decrease in the dual innovation performance of enterprises.

Based on the above analysis, the following hypotheses are proposed:

Hypothesis (3a): There is an inverted U-Curve relationship between the knowledge-based network structure hole and the exploitative innovation performance.

Hypothesis (3b): There is an inverted U-Curve relationship between the knowledge-based network structure hole and exploratory innovation performance.

\section{Method}

\section{Sample and Data}

The technology of the electronic information industry has developed rapidly and has extensive experience in innovation. This article takes the enterprises having gone public in shanghai and Shenzhen stock markets of the electronic information industry of China as the research objects and referring to previous research on the knowledgebased network structure obtains patents for five years from 2014 to 2018 from the "National Key Industry Patent Information Service Platform" database. Other data are obtained from the CSMAR database. The samples with missing values are excluded, a total of 269 valid samples are obtained.

\section{Measures}

\section{Dependent Variables}

This paper refers to the measurement method of dual innovation performance proposed by Guan \& Liu, the technical categories included in all patents of enterprises from 1985-2011 is as the basis, then we count the patents in the same technology category and the patents in the new technology category between 2014-2018 respectively. The exploitative innovation performance is measured by the increased number of the same type of patents compared to 1985-2011. The exploratory innovation performance is measured by the number of the new type of patents compared to 1985-2011 (Guan \& Liu, 2016). 


\section{Independent Variables}

Drawing on the research of Yayavaram \& Ahuja, the knowledge base is regarded as a network, the nodes represent the knowledge-based elements, the edges represent the connections between the knowledge-based elements (Yayavaram \& Ahuja, 2008). According to the International Technology Classification Standard (IPC), patent technology is divided into parts, divisions, large classes, small classes, main groups, and groups. This paper classifies them according to the technical standards of large classes. If an enterprise's patented technology belongs to two large classes, there is a connection between the knowledge-based elements, in other words there is a connection between the two nodes. As shown in Figure 1, nodes $1,2,3$, and 4 respectively represent the types of large classes in the technical classification standard, which are called knowledge-based elements. When a patent technology belongs to both 1 and 3 categories, a connection will be formed between the two knowledge-based elements. When a patent technology belongs to both 1 and 4 categories, a connection will be formed between the two knowledgebased elements, and the formation principle of other connections is the same. This paper builds an enterprise knowledge-based network through UCINNET 6.0 and calculates the structure eigenvalues of the knowledge-based network (Liu, 2009).

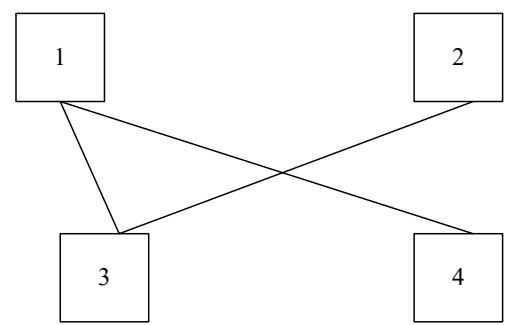

Figure 1. Schematic Diagram of Knowledge-based Network Structure

(1) Density. Network density is one of the important characteristics of the network structure. It is the ratio of the actual number of connections in the network to the maximum number of possible connections. The calculation formula is:

$$
\text { density }=\frac{l}{n(\mathrm{n}-1) / 2}
$$

Among them, 1 denotes the actual number of connections in the knowledge-based network, and $\mathrm{n}$ denotes the number of nodes in the knowledge-based network. Because the network density expressed by this formula is determined by the number of nodes, the knowledge-based networks density of different scales is not comparable. This paper uses the research of Kesselheim (Kesselheim \& Avorn, 2010) to calculate the absolute network density. The calculation formula is as follows:

$$
\text { density }^{\prime}=\frac{l}{\left(4 c r^{3} / 3 d\right)}
$$

Among them, 1 denotes the actual number of connections in the network; $\mathrm{C}$ denotes the longest path in the network; $d$ denotes the possible shortest path between the two points with the longest path; $r$ denotes the radius of the network, that is, $r=(1 / 2) \mathrm{d}$.

(2) Centralization. The centralization $r$ indicates whether the formation of the enterprise knowledge-based network structure revolves around one or several points. The calculation formula is as follows:

$$
\text { Centralization }_{D}=\frac{\sum_{i=1}^{n}\left[C_{D}\left(\mathrm{n}^{*}\right)-C_{D}\left(\mathrm{n}_{i}\right)\right]}{\max \sum_{i=1}^{n}\left[C_{D}\left(\mathrm{n}^{*}\right)-C_{D}\left(\mathrm{n}_{i}\right)\right]}
$$

Among them, $C_{D}\left(\mathrm{n}^{*}\right)$ is the maximum absolute degree of node in the knowledge-based network, $C_{D}\left(\mathrm{n}_{i}\right)$ is the absolute centralization of each node, $\mathrm{N}$ is the number of nodes in the knowledge-based network. Numerator represents the sum of the difference between the maximum absolute centrality and the absolute centrality of all nodes in the knowledge-based network. Denominator represents the possible maximum of numerator. The greater the centralization of enterprise knowledge-based network structure, the more the enterprise depends on one or more knowledge-based elements.

(3) Structure hole. Structure hole represents "bridge" nodes connecting two unrelated knowledge elements, and each "bridge" represents a structure hole. Enterprise knowledge-based network with structure hole can help enterprises obtain more information, and can occupy more differentiated information for information integration (Mcevily \& Zaheer, 1999). Butt's structure hole index has four dimensions: effective scale, efficiency, limitation, and grade. To explain the role of structure hole in the process of dual innovation, this paper uses the effective scale to measure, and the formula is as follows:

$$
c=\sum_{j}\left(1-\sum_{q} p_{i q} m_{j q}\right)
$$

Among them, $\sum_{q} p_{i q} m_{j q}$ represents the redundancy of knowledge-based network structure. The sum of the individual size of all knowledge-based elements minus the redundancy of the network is the effective scale of the knowledge-based network structure.

\section{Control Variables}

To reduce the impact of other factors on the dual innovation performance, combined with previous research on innovation performance, this paper regards enterprise size, R\&D intensity, knowledge-based scale, enterprise establishment period, enterprise location and enterprise nature as control variables. Among them, enterprise size is 
Hao Jia-Jia, Li Chunling, Yuan Runsen, Khansa Pervaiz, Muhammad Asif Khan, Sun Xiaoran. Dual Innovation ...

expressed by the logarithm of their business income; the $R \& D$ intensity is expressed by the proportion of their annual R\&D investment to their annual business income; the knowledge-based scale is expressed by the number of patent types of enterprises in the previous year; enterprise establishment period is expressed by the number of years of establishment of enterprises; and enterprise location belongs to the eastern, central and western parts of the country according to the location of enterprises registered, which is expressed by three virtual variables: 0,1 and 2 . The enterprise nature includes two cases: non-state-owned and state-owned, which are represented by two virtual variables: 0 and 1 .

The dependent variable is non-negative counting. According to Hausman et.al (Hausman, Hall \& Griliches, 1984), we use the negative binomial regression model for analysis, which is realized by stata14.0. Continuous numeric variables are winsorized at $99 \%$ level.

\section{Results}

\section{Regression Model}

$y_{j}=\alpha_{0 i}+\beta_{1 i} x_{i}+\beta_{2 i} x_{i}^{2}+\sum_{m=1}^{6} \beta_{3 m} z_{m}+\varepsilon_{i}$

Among them, $y_{j}$ denotes the dependent variable, $x_{i}$ denotes the independent variable, $z_{m}$ denotes the control variable, and $\varepsilon_{i}$ denotes the random error term.

\section{Descriptive Statistics}

The correlation coefficients and mean values of all variables are shown in table 1 . The correlation coefficient of all variables does not exceed 0.6. Knowledge-based scale is expressed by the number of patent types of enterprises in the previous year, it will be affected by R\&D investment, it has high correlation with the enterprise's R\&D investment, so knowledge-based scale's VIF is to 9.470 , but not more than 10. The VIF of other variables are less than 2.5. So, there is no serious multiple collinearity among the variables. These variables can be added to the regression equation for regression analysis.

Table 1

Correlation Coefficient and Descriptive Statistics of Main Variables

\begin{tabular}{|c|c|c|c|c|c|c|c|c|c|}
\hline variable & 1 & 2 & 3 & 4 & 5 & 6 & 7 & 8 & 9 \\
\hline lexploitative innovation & 1 & & & & & & & & \\
\hline 2exploratory innovation & 0.0790 & 1 & & & & & & & \\
\hline 3 density & $-0.1070^{*}$ & 0.0520 & 1 & & & & & & \\
\hline 5 structure hole & $0.1160 *$ & 0.0510 & $-0.2700 * * *$ & 0.0620 & 1 & & & & \\
\hline 6 enterprise size & $-0.1340 * *$ & -0.035 & 0.0740 & $-0.22 * * *$ & -0.0270 & 1 & & & \\
\hline $7 R \& D$ investment & -0.0130 & $-0.11^{*}$ & -0.0120 & 0.0310 & $-0.139 * *$ & -0.0350 & 1 & & \\
\hline 8 establishment period & 0.0850 & 0.0890 & $-0.1870 * * *$ & -0.0270 & $0.172 * * *$ & -0.0210 & -0.0330 & 1 & \\
\hline 9 knowledge-based scale & 0.0780 & 0.0100 & $-0.4380 * * *$ & 0.0620 & $0.344 * * *$ & -0.0180 & $-0.16^{* * *}$ & $0.171 * * *$ & 1 \\
\hline 10 eastern & 0.0620 & 0.0700 & -0.0160 & 0.0510 & 0.0120 & 0.0260 & $-0.145^{* *}$ & -0.0270 & 0.0100 \\
\hline 11 central & -0.0370 & -0.063 & -0.0480 & -0.0520 & -0.0750 & -0.0480 & $0.148 * *$ & -0.0520 & -0.0700 \\
\hline 12 western & -0.0460 & -0.030 & 0.0730 & -0.0160 & 0.0630 & 0.0140 & 0.0440 & 0.0920 & 0.0590 \\
\hline 13 state-owned & -0.0130 & -0.079 & $0.311 * * *$ & -0.0790 & $-0.296 * *$ & $-0.103 *$ & -0.0510 & $-0.216 * * *$ & $-0.242 * *$ \\
\hline 14 non-state-owned & 0.0130 & 0.0790 & $-0.311 * * *$ & 0.0790 & $0.296 * * *$ & $0.103 *$ & 0.0510 & $0.216^{* * *}$ & $0.242 * * *$ \\
\hline mean & 16.3200 & 0.7780 & 0.4860 & 1.4770 & 7.1180 & 4.2830 & 7.2780 & 18.340 & 9.405 \\
\hline Standard deviation & 10.2500 & 1.1570 & 0.3480 & 4.2290 & 5.8070 & 1.6790 & 5.4520 & 4.5280 & 8.946 \\
\hline
\end{tabular}

\begin{tabular}{|c|c|c|c|c|c|}
\hline variable & $\mathbf{1 0}$ & 11 & 12 & 13 & 14 \\
\hline 10 eastern & 1 & & & & \\
\hline 11 central & $-0.592 * * *$ & 1 & & & \\
\hline 12 western & $-0.449 * * *$ & $-0.100 *$ & 1 & & \\
\hline 13 state-owned & 0.0330 & -0.0230 & -0.0220 & 1 & \\
\hline 14 non-state-owned & -0.0330 & 0.0230 & 0.0220 & $-0.42 * * *$ & 1 \\
\hline
\end{tabular}

Note: $* * * p<0.01, * * p<0.05, * p<0.1$, enterprise location and enterprise nature are virtual variables, so, we do not report their mean, standard deviation and VIF

\section{Analysis of Regression Results}

Table 2 shows the regression results. Model 1 and model 2 examine the effects of control variables on exploitative innovation and exploratory innovation. Model 3 to model 8 test the impact of independent variable on dual innovation performance. 
Table 2

The Result of Negative Binomial Regression

\begin{tabular}{|c|c|c|c|c|c|c|c|c|}
\hline & Model 1 & Model 2 & Model 3 & Model 4 & Model 5 & Model 6 & Model 7 & Model 8 \\
\hline & $\begin{array}{l}\text { Exploitative } \\
\text { innovation }\end{array}$ & $\begin{array}{l}\text { Exploratory } \\
\text { innovation }\end{array}$ & $\begin{array}{l}\text { Exploitative } \\
\text { innovation }\end{array}$ & $\begin{array}{l}\text { Exploratory } \\
\text { innovation }\end{array}$ & $\begin{array}{l}\text { Exploitative } \\
\text { innovation }\end{array}$ & $\begin{array}{c}\text { Exploratory } \\
\text { innovation }\end{array}$ & $\begin{array}{l}\text { Exploitative } \\
\text { innovation }\end{array}$ & $\begin{array}{c}\text { Exploratory } \\
\text { innovation }\end{array}$ \\
\hline$R \& D$ investment & $\begin{array}{c}0.0447 * * * \\
(4.4800)\end{array}$ & $\begin{array}{l}-0.0082(- \\
0.4200)\end{array}$ & $\begin{array}{l}0.000302 \\
(0.0400)\end{array}$ & $\begin{array}{c}-0.0286 \\
(-1.6300)\end{array}$ & $\begin{array}{l}-0.000710 \\
(-0.0900)\end{array}$ & $\begin{array}{c}0.00823 \\
(0.3900)\end{array}$ & $\begin{array}{l}0.000737 \\
(0.1000)\end{array}$ & $\begin{array}{c}-0.0236 \\
(-1.3200)\end{array}$ \\
\hline $\begin{array}{c}\text { Enterprise } \\
\text { establishment } \\
\text { period }\end{array}$ & $\begin{array}{l}-0.0114(- \\
0.8800)\end{array}$ & $\begin{array}{c}0.0136 \\
(0.6900)\end{array}$ & $\begin{array}{c}0.0066 \\
(0.7400)\end{array}$ & $\begin{array}{c}0.0304 \\
(1.4800)\end{array}$ & $\begin{array}{l}0.0087 \\
(0.95)\end{array}$ & $\begin{array}{c}0.0102 \\
(0.4400)\end{array}$ & $\begin{array}{c}0.0107 \\
(1.1300)\end{array}$ & $\begin{array}{c}0.0322 \\
(1.5700)\end{array}$ \\
\hline $\begin{array}{l}\text { Knowledge-based } \\
\text { scale }\end{array}$ & $\begin{array}{l}0.0895 * * * \\
(14.9900)\end{array}$ & $\begin{array}{l}0.0178^{*} \\
(1.9300)\end{array}$ & $\begin{array}{c}-0.0268 \\
(-1.6000)\end{array}$ & $\begin{array}{l}-0.0754 * * \\
(-2.2100)\end{array}$ & $\begin{array}{l}-0.0181 \\
(-0.97)\end{array}$ & $\begin{array}{c}0.0539 * * * \\
(3.1700)\end{array}$ & $\begin{array}{c}-0.0112 \\
(-0.5800)\end{array}$ & $\begin{array}{l}-0.0608^{*} \\
(-1.8000)\end{array}$ \\
\hline Enterprise size & $\begin{array}{c}0.0579 \\
(0.8200) \\
\end{array}$ & $\begin{array}{c}0.0494 \\
(0.3700)\end{array}$ & $\begin{array}{c}-0.0661 * * * \\
(-2.8500)\end{array}$ & $\begin{array}{c}-0.0272 \\
(-0.5000)\end{array}$ & $\begin{array}{c}-0.0612 * * \\
(-2.58)\end{array}$ & $\begin{array}{c}0.1180 \\
(0.6400)\end{array}$ & $\begin{array}{c}-0.0617 * * * \\
(-2.6800)\end{array}$ & $\begin{array}{c}-0.0373 \\
(-0.6800)\end{array}$ \\
\hline eastern & $\begin{array}{c}0.267 \\
(1.300)\end{array}$ & $\begin{array}{c}0.492 \\
(1.430)\end{array}$ & $\begin{array}{c}0.0584 \\
(0.430)\end{array}$ & $\begin{array}{l}0.259 \\
(0.820)\end{array}$ & $\begin{array}{l}0.148 \\
(0.970)\end{array}$ & $\begin{array}{c}-0.210 \\
(-0.560)\end{array}$ & $\begin{array}{l}0.103 \\
(0.680)\end{array}$ & $\begin{array}{l}0.284 \\
(0.840)\end{array}$ \\
\hline central & $\begin{array}{c}0.252 \\
(0.960)\end{array}$ & $\begin{array}{c}0.429 \\
(1.100)\end{array}$ & $\begin{array}{l}-0.0780 \\
(-0.400)\end{array}$ & $\begin{array}{c}-0.183 \\
(-0.410)\end{array}$ & $\begin{array}{l}0.0553 \\
(0.270)\end{array}$ & $\begin{array}{l}-0.908^{* * *} \\
(-2.140)\end{array}$ & $\begin{array}{l}0.0240 \\
(0.902)\end{array}$ & $\begin{array}{c}0.162 \\
(0.370)\end{array}$ \\
\hline western & $\begin{array}{c}0.143 \\
(1.610)\end{array}$ & $\begin{array}{l}0.223 * \\
(1.230)\end{array}$ & $\begin{array}{c}0.0431 \\
(0.327)\end{array}$ & $\begin{array}{l}0.112 * * \\
(0.643)\end{array}$ & $\begin{array}{l}0.098 \\
(0.170)\end{array}$ & $\begin{array}{c}-0.112 \\
(-0.490)\end{array}$ & $\begin{array}{l}0.093 \\
(0.652)\end{array}$ & $\begin{array}{l}0.143 * * \\
(0.754)\end{array}$ \\
\hline state-owned & $\begin{array}{c}0.337 \\
(2.340)\end{array}$ & $\begin{array}{l}0.257^{*} \\
(1.644)\end{array}$ & $\begin{array}{l}-0.0233 \\
(-0.654)\end{array}$ & $\begin{array}{l}0.217 \\
(0.850)\end{array}$ & $\begin{array}{l}-0.073 * * \\
(-0.643)\end{array}$ & $\begin{array}{c}-0.352 \\
(-1.430)\end{array}$ & $\begin{array}{c}-0.0261 \\
(-0.137)\end{array}$ & $\begin{array}{l}-0.154^{*} \\
(-1.210)\end{array}$ \\
\hline non-state-owned & $\begin{array}{c}0.421 * * * \\
(3.480)\end{array}$ & $\begin{array}{l}-0.368^{*} \\
(-1.740)\end{array}$ & $\begin{array}{c}-0.0394 \\
(-0.460)\end{array}$ & $\begin{array}{c}-0.207 \\
(-0.970)\end{array}$ & $\begin{array}{c}-0.00557 \\
(-0.0700)\end{array}$ & $\begin{array}{c}-0.442 \\
(-1.530)\end{array}$ & $\begin{array}{l}-0.0132 \\
(-0.150)\end{array}$ & $\begin{array}{c}-0.239 \\
(-1.150)\end{array}$ \\
\hline Density & & & $\begin{array}{l}2.2760^{* *} \\
(2.4200) \\
\end{array}$ & $\begin{array}{c}-1.9740 \\
(-0.9100) \\
\end{array}$ & $\begin{array}{c}-0.1720 \\
(-0.9400) \\
\end{array}$ & $\begin{array}{c}1.3230^{*} \\
(1.7600) \\
\end{array}$ & $\begin{array}{c}0.0834 \\
(0.3700) \\
\end{array}$ & $\begin{array}{c}1.6290^{* * *} \\
(3.0200) \\
\end{array}$ \\
\hline Centralization & & & $\begin{array}{l}-0.0225^{* *} \\
(-2.2400) \\
\end{array}$ & $\begin{array}{c}0.0396^{*} \\
(1.9400) \\
\end{array}$ & $\begin{array}{c}-0.0640^{* *} \\
(-1.6700) \\
\end{array}$ & $\begin{array}{c}18.6700 \\
(1.3700) \\
\end{array}$ & $\begin{array}{l}-0.0211 * * \\
(-2.0400) \\
\end{array}$ & $\begin{array}{c}0.0369^{*} \\
(1.7200) \\
\end{array}$ \\
\hline Structure hole & & & $\begin{array}{l}0.0675^{* *} \\
(2.0800) \\
\end{array}$ & $\begin{array}{l}0.1280^{* *} \\
(2.1500)\end{array}$ & $\begin{array}{c}0.0324 \\
(1.0200) \\
\end{array}$ & $\begin{array}{c}-0.0381 （- \\
0.6500)\end{array}$ & $\begin{array}{l}0.1000^{* *} \\
(-2.1600) \\
\end{array}$ & $\begin{array}{c}0.2910^{* * *} \\
(2.9300) \\
\end{array}$ \\
\hline Density $^{2}$ & & & $\begin{array}{c}-1.8790 * * * \\
(-2.7200) \\
\end{array}$ & $\begin{array}{c}2.3490 \\
(1.4200) \\
\end{array}$ & & & & \\
\hline Centralization $^{2}$ & & & & & $\begin{array}{c}0.00256 \\
(1.1000) \\
\end{array}$ & $\begin{array}{l}-1.4340^{*} \\
(-1.7200) \\
\end{array}$ & & \\
\hline Structure hole ${ }^{2}$ & & & & & & & $\begin{array}{c}-0.00296^{* *} \\
(-2.1600)\end{array}$ & $\begin{array}{c}-0.00584 * \\
(-1.8600)\end{array}$ \\
\hline Constant & $\begin{array}{c}2.8880 * * * \\
(9.9500)\end{array}$ & $\begin{array}{l}-1.5060 * * \\
(-2.1700)\end{array}$ & $\begin{array}{c}2.2900 * * * \\
(6.1500)\end{array}$ & $\begin{array}{c}-0.7670 \\
(-1.0100)\end{array}$ & $\begin{array}{c}2.8370 * * * \\
(8.0200)\end{array}$ & $\begin{array}{c}0.5230 \\
(0.4000)\end{array}$ & $\begin{array}{c}2.3940 * * * \\
(5.6500)\end{array}$ & $\begin{array}{l}-2.5620^{* *} \\
(-2.5800)\end{array}$ \\
\hline Log likelihood & -999.1000 & -317.1000 & -996.4000 & -316.2000 & -998.7000 & -185.200 & -997.2000 & -315.6000 \\
\hline $\begin{array}{l}\text { Wald chi }{ }^{2} \\
\text { (p value) }\end{array}$ & $\begin{array}{c}18.36 \\
(0.061) \\
\end{array}$ & $\begin{array}{c}25.32 \\
(0.074) \\
\end{array}$ & $\begin{array}{c}25.8 \\
(0.000) \\
\end{array}$ & $\begin{array}{c}27.03 \\
(0.043) \\
\end{array}$ & $\begin{array}{c}20.93 \\
(0.085) \\
\end{array}$ & $\begin{array}{c}45.1 \\
(0.033) \\
\end{array}$ & $\begin{array}{c}23.33 \\
(0.027) \\
\end{array}$ & $\begin{array}{c}25.3 \\
(0.064) \\
\end{array}$ \\
\hline $\mathrm{N}$ & 269 & 269 & 269 & 269 & 269 & 269 & 269 & 269 \\
\hline
\end{tabular}

Note: Density ${ }^{2}$ represents the square of Density, Centralization ${ }^{2}$ represents the square of Centralization, Structure hole ${ }^{2}$ represents the square of structure hole. ${ }^{* *} p<0.01, * * p<0.05, * p<0.1$.

In Model 1, the regression coefficient of $R \& D$ investment is 0.0447 . The regression coefficient of knowledge-based scale is 0.0895 . Both regression coefficients are significant at the level of $1 \%$, which indicates that R\&D investment and knowledge-based scale have a significant positive effect on the exploitative innovation of enterprises. The larger the knowledge-based scale is, the more knowledge elements the enterprise can refer to and the better the exploitative innovation performance will be. The more R\&D investment is, the more resources the enterprise can obtain and the better the exploitative innovation performance will be. In Model 2, the regression coefficient of knowledge-based scale is 0.0178 significant at the level of $10 \%$. So, the knowledge-based scale has positive effect on exploratory innovation. Enterprises have a certain dependence on the original knowledge base when carrying out exploratory innovation. The larger the knowledge-based scale, the better the exploratory innovation performance.
In Model 3, the square of coefficient density is -1.8790 significant at the level of $1 \%$. There is an inverted U-Curve relationship between the knowledge-based network density and the exploitative innovation. Hypothesis 1a is confirmed. In Model 4, the square of coefficient of the knowledgebased network density is positive and not significant. There is no inverted U-Curve relationship between the density and exploratory innovation. In this article, hypothesis $1 \mathrm{~b}$ is rejected.

In Model 5, the square of coefficient of centralization and exploitative innovation are not significant, so hypothesis $2 \mathrm{a}$ is rejected. In Model 6, the square of coefficient of centralization is -1.434 significant at the level of $10 \%$. There is an inverted U-shaped relationship between the centralization and exploratory innovation. Hypothesis $2 \mathrm{~b}$ is confirmed.

In Model 7, the square of coefficient of structure hole is -0.00296 significant at the level of $5 \%$; in Model 8 , the square of coefficient of structure hole is -0.00584 significant at the level of $10 \%$. The knowledge-based network structure 
Hao Jia-Jia, Li Chunling, Yuan Runsen, Khansa Pervaiz, Muhammad Asif Khan, Sun Xiaoran. Dual Innovation ...

hole has an inverted U-Curve relationship with exploitative innovation and exploratory innovation. Hypothesis $3 \mathrm{a}$ and hypothesis $3 \mathrm{~b}$ are confirmed.

\section{Robust Test}

To verify the robustness of the results, this paper verifies the robustness of the results from the perspectives of statistical methods and regression model. First, we redefine the basic patent window period and use the technology categories included in all patents of the enterprises in 2004 2008 as a basis for judgment. Compared 2014-2018 to 2004
2008 , the same type of patents increasing each year is as exploitative innovation performance and the number of new types of patents increasing each year is as exploratory innovation performance. The regression results of Model 9 to Model 12 show that hypotheses 1a, 2b, 3a, and $3 \mathrm{~b}$ are confirmed. Second, the hypothesis is tested using a fixedeffect negative binomial regression model. The regression coefficients of Model 13 to Model 16 are in the same direction as the regression results above. Hypotheses 1a, 2b, 3a, and $3 \mathrm{~b}$ are confirmed. Table 3 shows the robustness regression results.

Robust Test

Table 3

\begin{tabular}{|c|c|c|c|c|c|c|c|c|}
\hline & Model 9 & Model 10 & Model 11 & Model 12 & Model 13 & Model 14fe & Model 15fe & Model 16fe \\
\hline & $\begin{array}{l}\text { Exploitative } \\
\text { innovation }\end{array}$ & $\begin{array}{c}\text { Exploratory } \\
\text { innovation }\end{array}$ & $\begin{array}{c}\text { Exploitative } \\
\text { innovation }\end{array}$ & $\begin{array}{l}\text { Exploratory } \\
\text { innovation }\end{array}$ & $\begin{array}{l}\text { Exploitative } \\
\text { innovation }\end{array}$ & $\begin{array}{c}\text { Exploratory } \\
\text { innovation }\end{array}$ & $\begin{array}{l}\text { Exploitative } \\
\text { innovation }\end{array}$ & $\begin{array}{c}\text { Exploratory } \\
\text { innovation }\end{array}$ \\
\hline$R \& D$ investment & $\begin{array}{l}0.000212 \\
(0.0300)\end{array}$ & $\begin{array}{l}0.00815 \\
(0.400)\end{array}$ & $\begin{array}{l}0.000740 \\
(0.1030) \\
\end{array}$ & $\begin{array}{c}-0.0233 \\
(-1.3310) \\
\end{array}$ & $\begin{array}{l}0.000332 \\
(0.4680)\end{array}$ & $\begin{array}{c}0.00769 \\
(0.2770) \\
\end{array}$ & $\begin{array}{l}0.000734 \\
(0.1120) \\
\end{array}$ & $\begin{array}{c}-0.0245 \\
(-1.322) \\
\end{array}$ \\
\hline $\begin{array}{c}\text { Enterprise } \\
\text { establishment } \\
\text { period }\end{array}$ & $\begin{array}{c}0.00532 \\
(0.6800)\end{array}$ & $\begin{array}{c}0.0110 \\
(0.4510)\end{array}$ & $\begin{array}{c}0.0107 \\
(1.1410)\end{array}$ & $\begin{array}{c}0.0322 \\
(1.5660)\end{array}$ & $\begin{array}{c}0.00711 \\
(0.7550)\end{array}$ & $\begin{array}{c}0.0100 \\
(0.3670)\end{array}$ & $\begin{array}{c}0.0100 \\
(1.1520)\end{array}$ & $\begin{array}{c}0.0319 \\
(1.5730)\end{array}$ \\
\hline $\begin{array}{c}\text { Knowledge-based } \\
\text { scale }\end{array}$ & $\begin{array}{c}-0.0259 \\
(-1.8000) \\
\end{array}$ & $\begin{array}{c}0.0541 * * * \\
(2.9010)\end{array}$ & $\begin{array}{c}-0.0110 \\
(-0.6010) \\
\end{array}$ & $\begin{array}{l}-0.0611^{*} \\
(-1.7990) \\
\end{array}$ & $\begin{array}{c}-0.0273 \\
(-1.5000) \\
\end{array}$ & $\begin{array}{c}0.0552 * * * \\
(4.1600) \\
\end{array}$ & $\begin{array}{c}-0.0125 \\
(-0.6210) \\
\end{array}$ & $\begin{array}{l}-0.0587^{*} \\
(-1.8030) \\
\end{array}$ \\
\hline Enterprise size & $\begin{array}{c}-0.0701 * * * \\
(-2.7860)\end{array}$ & $\begin{array}{c}0.1200 \\
(0.6380)\end{array}$ & $\begin{array}{c}-0.0599 * * * \\
(-2.7000)\end{array}$ & $\begin{array}{c}-0.0373 \\
(-0.6780)\end{array}$ & $\begin{array}{c}-0.0653 * * * \\
(-2.9100)\end{array}$ & $\begin{array}{c}0.1000 \\
(0.6430)\end{array}$ & $\begin{array}{c}-0.0622 * * * \\
(-2.6810)\end{array}$ & $\begin{array}{c}-0.0369 \\
(-0.6830) \\
\end{array}$ \\
\hline eastern & $\begin{array}{c}0.135 \\
(1.601)\end{array}$ & $\begin{array}{c}0.500 \\
(1.334)\end{array}$ & $\begin{array}{c}0.0492 \\
(0.455) \\
\end{array}$ & $\begin{array}{c}0.301 \\
(0.733) \\
\end{array}$ & $\begin{array}{c}0.121 \\
(0.876)\end{array}$ & $\begin{array}{c}-0.201 \\
(-0.453)\end{array}$ & $\begin{array}{c}0.112 \\
(0.534) \\
\end{array}$ & $\begin{array}{c}0.276 \\
(0.765) \\
\end{array}$ \\
\hline central & $\begin{array}{c}0.134 \\
(0.876)\end{array}$ & $\begin{array}{c}0.433 \\
(1.112)\end{array}$ & $\begin{array}{c}-0.087 \\
(-0.398)\end{array}$ & $\begin{array}{c}-0.176 \\
(-0.321)\end{array}$ & $\begin{array}{c}0.054 \\
(0.241)\end{array}$ & $\begin{array}{c}-0.954 * * \\
(-2.21)\end{array}$ & $\begin{array}{c}0.034 \\
(0.912)\end{array}$ & $\begin{array}{c}0.155 \\
(0.242)\end{array}$ \\
\hline western & $\begin{array}{c}0.133 \\
(1.534) \\
\end{array}$ & $\begin{array}{c}0.232 * \\
(1.113) \\
\end{array}$ & $\begin{array}{c}0.054 \\
(0.366) \\
\end{array}$ & $\begin{array}{l}0.107 * * \\
(0.564)\end{array}$ & $\begin{array}{c}0.101 \\
(0.098) \\
\end{array}$ & $\begin{array}{c}-0.107 \\
(-0.500) \\
\end{array}$ & $\begin{array}{c}0.075 \\
(0.599) \\
\end{array}$ & $\begin{array}{l}0.164 * * \\
(0.654)\end{array}$ \\
\hline state-owned & $\begin{array}{c}0.402 \\
(2.12) \\
\end{array}$ & $\begin{array}{c}0.266^{*} \\
(1.532) \\
\end{array}$ & $\begin{array}{c}-0.022 \\
(-0.543) \\
\end{array}$ & $\begin{array}{c}0.123 \\
(0.176) \\
\end{array}$ & $\begin{array}{l}-0.068 * * \\
(-0.564) \\
\end{array}$ & $\begin{array}{c}-0.234 \\
(-1.442) \\
\end{array}$ & $\begin{array}{c}-0.323 \\
(-0.154) \\
\end{array}$ & $\begin{array}{l}-0.132^{*} \\
(-1.233) \\
\end{array}$ \\
\hline non-state-owned & $\begin{array}{c}0.432 * * * \\
(3.760)\end{array}$ & $\begin{array}{c}-0.378^{*} \\
(-1.660)\end{array}$ & $\begin{array}{c}-0.0298 \\
(-0.501)\end{array}$ & $\begin{array}{c}-0.102 \\
(-0.863) \\
\end{array}$ & $\begin{array}{c}-0.00476 \\
(-0.0699) \\
\end{array}$ & $\begin{array}{c}-0.500 \\
(-1.470) \\
\end{array}$ & $\begin{array}{l}-0.0122 \\
(-0.130)\end{array}$ & $\begin{array}{c}-0.265 \\
(-1.130)\end{array}$ \\
\hline Density & $\begin{array}{l}2.2690 * * \\
(2.3990) \\
\end{array}$ & $\begin{array}{c}1.3210^{*} \\
(1.7710) \\
\end{array}$ & $\begin{array}{c}0.0841 \\
(0.3520) \\
\end{array}$ & $\begin{array}{c}1.6300 * * * \\
(3.0000)\end{array}$ & $\begin{array}{l}2.2800 * * \\
(2.5100)\end{array}$ & $\begin{array}{c}1.3350 * \\
(1.8040) \\
\end{array}$ & $\begin{array}{c}0.0830 \\
(0.3880) \\
\end{array}$ & $\begin{array}{c}1.6110 * * * \\
(3.0200) \\
\end{array}$ \\
\hline Centralization & $\begin{array}{l}-0.0223 * * \\
(-2.2380) \\
\end{array}$ & $\begin{array}{c}17.9700 \\
(1.3660) \\
\end{array}$ & $\begin{array}{l}-0.0210^{* *} \\
(-2.0410) \\
\end{array}$ & $\begin{array}{c}0.0372 * \\
(1.7160) \\
\end{array}$ & $\begin{array}{l}-0.0216^{* *} \\
(-2.1950) \\
\end{array}$ & $\begin{array}{c}16.6700 \\
(1.2830)\end{array}$ & $\begin{array}{l}-0.0205^{* *} \\
(-2.0330) \\
\end{array}$ & $\begin{array}{c}0.0355^{*} \\
(1.7230) \\
\end{array}$ \\
\hline Structure hole & $\begin{array}{l}0.0667 * * \\
(2.1000)\end{array}$ & $\begin{array}{l}-0.0383(- \\
0.6440)\end{array}$ & $\begin{array}{l}0.1020^{* *} \\
(-2.1550)\end{array}$ & $\begin{array}{c}0.3000 * * * \\
(2.9250)\end{array}$ & $\begin{array}{l}0.0575 * * \\
(2.2400)\end{array}$ & $\begin{array}{c}-0.03941 （- \\
0.6660)\end{array}$ & $\begin{array}{l}0.1130 * * \\
(-2.1640)\end{array}$ & $\begin{array}{c}0.2870 * * * \\
(2.9350)\end{array}$ \\
\hline Density $^{2}$ & $\begin{array}{c}-1.9010 * * * \\
(-2.6940)\end{array}$ & & & & $\begin{array}{c}-1.7990 * * * \\
(-2.6850)\end{array}$ & & & \\
\hline Centralization $^{2}$ & & $\begin{array}{l}-1.4220^{*} \\
(-1.7180) \\
\end{array}$ & & & & $\begin{array}{l}-1.5140^{*} \\
(-1.6890) \\
\end{array}$ & & \\
\hline Structure hole ${ }^{2}$ & & & $\begin{array}{c}-0.00296 * * \\
(-2.1600)\end{array}$ & $\begin{array}{l}-0.00591 * \\
(-1.8550)\end{array}$ & & & $\begin{array}{c}-0.00301 * * \\
(-2.1570)\end{array}$ & $\begin{array}{l}-0.00580^{*} \\
(-1.7850)\end{array}$ \\
\hline Constant & $\begin{array}{c}3.0060 * * * \\
(6.2000)\end{array}$ & $\begin{array}{c}0.4550 \\
(0.4130)\end{array}$ & $\begin{array}{c}2.4010^{* * * *} \\
(5.5900)\end{array}$ & $\begin{array}{l}-2.558 * * \\
(-2.5800)\end{array}$ & $\begin{array}{c}2.3320 * * * \\
(6.0190)\end{array}$ & $\begin{array}{c}0.6410 \\
(0.4000)\end{array}$ & $\begin{array}{c}2.3880 * * * \\
(5.7320)\end{array}$ & $\begin{array}{l}-2.5700 * * \\
(-2.5760)\end{array}$ \\
\hline Log likelihood & -985.4000 & -179.2000 & -989.2000 & -320.6000 & -988.4000 & -180.2000 & -996.2000 & -323.6000 \\
\hline $\begin{array}{l}\text { Wald chi- square } \\
(\mathrm{p})\end{array}$ & $\begin{array}{c}25.5500 \\
(0.07)\end{array}$ & $\begin{array}{c}35.1000 \\
(0.03)\end{array}$ & $\begin{array}{c}23.4000 \\
(0.06)\end{array}$ & $\begin{array}{c}25.3000 \\
(0.00)\end{array}$ & $\begin{array}{c}25.7700 \\
(0.08)\end{array}$ & $\begin{array}{c}43.1300 \\
(0.005) \\
\end{array}$ & $\begin{array}{l}23.3700 \\
(0.0004)\end{array}$ & $\begin{array}{c}25.3000 \\
(0.08)\end{array}$ \\
\hline $\mathrm{N}$ & 269 & 269 & 269 & 269 & 269 & 269 & 269 & 269 \\
\hline
\end{tabular}

Note: $* * * p<0.01, * * p<0.05, * p<0.1$.

\section{Discussion}

This paper can help enterprises optimize of knowledgebased network structure, help enterprises achieve sustainable development by improving dual innovation performance, and increase the ecological carrying capacity.

(1) The essential function of science and technology is sustainable development. The sustainable function of science and technology mainly depends on the accumulation of its own energy and is exerted through technological innovation. Therefore, technological innovation has a huge positive effect on sustainable development. This positive effect is mainly reflected in the promotion of economic growth, the evolution of social forms, the protection and conservation of natural ecology and resources. The dual technological innovation has gradually enhanced the sustainable development capabilities of economic, social, and natural complex systems. First, exploratory innovation is the fundamental of economic growth. Exploratory innovation transforms the development mode of the enterprise, so that the production possibility boundary is expanded outward, and the sustainable 
development capability of the enterprise is enhanced. Second, exploitative innovation breaks the limit of resource supply, improves resource utilization efficiency, saves production factors, reduces consumption of resources, and enhances ecological carrying capacity. Finally, continuous technological innovation has shifted the social production mode from labor to intelligence and has gradually transformed the industrial structure from labor-intensive to knowledge-intensive.

(2) Innovation is the prerequisite for the survival of an enterprise. Innovation is the search, recombination of knowledge-based elements, and is also the creation of new knowledge by breaking through the original knowledge. A complete knowledge-based network structure is the foundation of a enterprise's technological innovation. The use method represents and determines the innovation direction of an enterprise. With different innovation development strategies, there are differences in the use of knowledge base. In the process of technological innovation, enterprises must change the concept if $R \& D$ investment increases, the innovation output will increase too. They must always pay attention to the correlation of knowledge-based elements, fully understand, and use the correlation of knowledge-based elements to improve the exploitative innovation performance and the exploratory innovation performance.

(3) The scale of the knowledge-based is affected by the degree to which the enterprise attaches importance to knowledge, and it is also affected by ability to accumulate knowledge. The more an enterprise emphasizes the importance of knowledge, the more it can stimulate the potential of employees, especially scientific researchers to learn new knowledge, which can increase the knowledge reserve and improve the knowledge-based network structure. Therefore, enterprises can infiltrate the concept of fulllearning to employees, encourage employees to take the initiative to learn new knowledge and a corporate atmosphere of full-member innovation can form. In addition, scientific researchers are still the core of enterprise for technology innovation. The learning ability of scientific researchers directly determines the knowledge-based scale and the knowledge-based network structure, which indirectly affects the innovation direction of the enterprise. Therefore, enterprises can cultivate scientific researchers who can create and search knowledge base for innovation, and reserve dual innovative talents for enterprises.

(4) A reasonable knowledge structure can enable enterprises to achieve the purpose of innovation though knowledge search and combination, but enterprises spend less. While innovation can create value for the enterprise, enterprise with excessive knowledge search in a single technology field will have "core rigidity", which will reduce the flexibility of the enterprise and make the enterprise lose the ability to explore new fields; too much technology field will disperse the enterprise's energy and the enterprise need to be ready to deal with fierce market competition without taking care of knowledge reserves and technological innovation. Therefore, when formulate an innovation and development strategy, an enterprise must have a detailed understanding of the knowledge base and the situation of scientific researchers and have a full grasp of the markets that have been involved and will be explored.

\section{Conclusions}

This article studies the influences of the knowledgebased network structure on dual innovation. The impact of knowledge-based network centrality, density, and structural hole on the performance of exploitative innovation and exploratory innovation are explored. The national strategy of "Strengthening Independent Innovation Capability and Building an Innovative Country" guides enterprises to continuously improve their innovation capabilities. Increasing $\mathrm{R} \& \mathrm{D}$ input can certainly increase innovation output. In the long run, increasing the input-output ratio has become the focus of enterprises. Knowledge base is the key to innovation, affecting the innovation direction and efficiency of enterprise innovation. The internal connection of knowledge-based elements can not only reflect the utilization of knowledge base by enterprises, but also reflect the innovation and development strategy of enterprises. Through empirical analysis of panel data of 269 enterprises in the electronic information industry, we find that knowledge-based network density, centralization, and structure holes have important effects on the dual innovation performance of enterprises.

First, there is an inverted U-Curve relationship between the density of knowledge-based networks and exploitative innovation. Similar to the study of the inverted U-shaped relationship between knowledge structure similarity, knowledge structure complementarity and enterprise innovation performance (Mao, Shi \& Chen, 2019), this paper studies the inverted U-shaped relationship between network density in knowledge structure and innovation performance When enterprise implements exploitative innovation development strategies, they pay attention to the knowledge base more and they understand fully the knowledge base, and some scholars also believe that knowledge base can improve innovation performance (Wang et al., 2014; Dibiaggio, Nasiriyar \& Nesta, 2014; Colombelli, 2014). In this case, enterprises can create new knowledge through knowledge search and combination at a small cost. Meanwhile, enterprises are more confident on innovation. In addition, when the relevance of knowledge is high, the enterprise can grasp the existing technology and understand the market demand of the exploitative innovation resulting from the recombination of knowledge, at the same time the enterprise can also create value fast. However, as the similarity of knowledge increases, the possibility of enterprises wanting to create new technologies through knowledge search and combination is reduced due to the limitation of technical personnel's ability and the increase of development costs, that is, the performance of exploitative innovation declines, and the enterprise falls into "technology dependence" dilemma. When the enterprises face an unstable market environment, too high knowledge-based network density will become a burden for enterprises to innovate. On the one hand, enterprises do not want to give up their existing knowledge, on the other hand, enterprises have no ability to develop new markets. Innovation activities have become inelastic and innovative performance declines.

Second, there is an inverted U-Curve relationship between the centralization of knowledge-based networks and long-term exploratory innovation performance. When the enterprise implements the development strategy of 
exploratory innovation, the knowledge is not highly relevant to the new technology areas that the enterprise is about to break through, and knowledge base can make smaller contribution to new technology research and development. Therefore, the knowledge base has no obvious impact on exploratory innovation in the short term. In the initial stage of exploratory innovation, enterprises need to overcome the problem of lack of knowledge and limitation of technical staff to capture new technical fields. With the deepening of research, enterprises have broken through technical bottlenecks and accumulated a certain knowledge base around existing research directions in new technology fields. Enterprises can continue to carry out exploratory innovation in this field around this core technology; however, with the amount of business increasing, enterprises need to consider the creation of new knowledge and maintain a competitive advantage in multiple technology areas. At this time, enterprises have to reduce their investment in creating new knowledge and developing new technologies, which leads to a decline in corporate innovation performance.

Third, different from the research on the indirect effect of knowledge-based network structure holes on innovation performance, this paper studies the direct relationship between knowledge-based network structure holes and innovation performance (Wang et al., 2019; Chen \& Zeng, 2019). There is an inverted U-Curve relationship between the structure hole of knowledge-based network and exploitative innovation, this U-Curve relationship is between the structure hole of knowledge-based network and exploratory innovation. When enterprises implement dual innovation strategies, with the high similarities of knowledge base in the technical fields, enterprises can more accurately use and combine knowledgebased elements for innovations. At the same time, enterprises only need to enter new technology fields with fewer key technologies, and the enterprise's existing technology and market are relatively concentrated, it will not distract the enterprise's energy to explore innovation.
Therefore, the lower knowledge-based network structure hole can positively promote the dual innovation performance of enterprises. With the enhancement of the enterprise's ability to explore and innovate, enterprise's ability to create new knowledge improves and the connection between knowledge-based elements decreases and even isolated knowledge-based elements may appear. This means that the level of enterprise technology diversification has increased, and market competition has increased fiercely. Currently enterprises have to cope with fierce market competition. Hence, no matter whether they carry out exploitation innovation or exploratory innovation, innovation costs and risks will increase, and dual innovation performance will be negatively affected.

This paper studies the relationship between knowledgebased network structure and dual innovation and finds the relationship between the characteristics of knowledge-based network structure and dual innovation performance, but there are also shortcomings. Firstly, Patent is explicit knowledge, which can reflect the innovation ability of an enterprise, and patent is studied in this research. Some explicit knowledge can also reflect the innovation ability of an enterprise, but tacit knowledge is not discussed in this study. Secondly, the industry selected in this article is the electronic information industry with obvious innovation, while other highinnovation products can also be used as samples to explore the relationship between the knowledge-based network structure and innovation performance. Finally, the enterprise knowledge-based network structure changes with thechanging of the enterprise's knowledge reserve. Different development stages of the enterprise correspond to different knowledge-based network structures. In the future, we will continue to study the impact of the knowledge-based network structure of different industries on the dual innovation performance which is reflected by tacit knowledge of enterprises. At the same time, we will study the relationship between the dynamically changing corporate knowledgebased network structure and dual innovation.

\section{Acknowledgement}

Funding: This research was funded by Major research project of humanities and social sciences of HeBei provincial department of education funding, grant number ZD201904

\section{References}

Burt, R. S. (1992). Structural Holes: The Social Structure of Competition. Cambridge, MA: Harvard University Press.

Chen, P., \& Zeng, D. M. (2019). The impact of network location and knowledge base on the performance of new product development of enterprises, Management Review, 31(11), 128-138.

Colombelli, A., Krafft, J., \& Quatraro, F. (2014). High-growth firms and technological knowledge: do gazelles follow exploration or exploitation strategies?, Industrial and Corporate Change, 3(1), 261-291. https://doi.org/10.10 93/icc/dtt053

Dibiaggio, L., Nasiriyar, M., \& Nesta, L. (2014). Substitutability and complementarity of technological knowledge and the inventive performance of semiconductor companies, Research Policy, 43(9), 1582-1593. https://doi.org/10.10 16/j.respol.2014.04.001

Fan, L.Q., \& Liu, W.W. (2014). Technology Acquisition Strategy and Absorptive Capability from the Perspective of Dualism--An Empirical Study Based on Chinese Experience, Studies in Science of Science, 32(2), 257-266.

Garcia-Vega, M. (2006). Does technological diversification promote innovation?: An empirical analysis for European firms, Research Policy, 35(2), 230-246. https://doi.org/10.1016/j.respol.2005.09.006 
Gibson, C. B., \& Birkinshaw, J. (2004). The antecedents, consequences, and mediating role of organizational ambidexterity, Academy of Management Journal, 47(2), 209-226. https://doi.org/10.5465/20159573

Guan, J. Ch. \& Liu, N. (2016). Exploitative and exploratory innovations in knowledge network and collaboration network: A patent analysis in the technological field of nano-energy, Research Policy, 45(1), 97-112. https://doi.org/10.10 16/j.respol.2015.08.002

Hausman, J., Hall, B. H., \& Griliches, Z. (1984). Econometric Models for Count Data with an Application to the PatentsR\&D Relationship, Econometrica, 52(4), 909-938. https://doi.org/10.2307/1911191

Henderson, R., \& Cockburn, I. (1994). Measuring Competence? Exploring Firm Effects in Pharmaceutical Research, Strategic Management Journal, 15(S1), 63-84. https://doi.org/10.1002/smj.4250150906

Henderson, R., \& Cockburn, I. (1996). Scale, scope, and spillovers: the determinants of research productivity in drug discovery, Rand Journal of Economics, 27(1), 32-59. https://doi.org/10.2307/2555791

Jia, H. Y., Wang, Z. J., \& Cao, Z. J. (2019). Exploration or Exploitative? Knowledge Structure and Evolution of Exploration and Exploitative, Scientific Research Management, 40(08), 113-125.

Junhui, H., \& Yi, Y. (2020). Network structure hole, knowledge base and enterprise dualistic innovation, Henan Social Sciences, 28(10), 104-111.

Kesselheim, A.S., \& Avorn, J. (2009). Using patent data to assess the value of pharmaceutical innovation, Journal of Law, Medicine \& Ethics, 37(2), 176-183. https://doi.org/10.1111/j.1748-720X.2009.00364.x

Liu, J. (2009). Lecture on Holistic Network Analysis: UCINET Software Practical Guide: a practical guide to UCINET. Shanghai: Gezhi Press.

Liu, L.Q., Lu, Sh.Y., \& Mei, Sh.Y. (2018). Pursuing the Development Track and Knowledge Structure of "Explore and Exploitative " Research--Based on Bibliometric Research, Modern Information, 38(03), 150-158.

Mao, D., Shi, J. J., \& Chen, X. L. (2019). An Empirical Study on the Impact of Knowledge Relevance on Innovation Performance-A Perspective of Enterprise Technology M \& A, Science \& Technology Progress and Policy, 36(15), 129136.

Mcevily, B., \& Zaheer, A. (1999). Bridging Ties: A Source of Firm Heterogeneity in Competitive Capabilities, Strategic Management Journal, 20(12), 1133-1151. https://doi.org/10.1002/(SICI)1097-0266(199912)20:12<1133::AIDSMJ74>3.0.CO;2-7

Miller, K. D. (2002). Top management, strategy and organizational knowledge inventory and managerial myopia, Strategic Management Journal, 23(8), 689-706. https://doi.org/10.1002/smj.245

Scott, J. (1988). Social network analysis. Sociology, 22(1), 109-127. https://doi.org/10.1177/0038038588022001007

Scott, J. (2016). Social Network Analysis. Chongqing: Chongqing University Press (in Chinese).

Shahraki, A. A. (2019). Sustainable regional development through knowledge networks: Review of case studies, Frontiers of Architectural Research, 8(4), 471-482. https://doi.org/10.1016/j.foar.2019.04.004

Tsouri, M., Hanson, J., \& Normann, H. E. (2021). Does participation in knowledge networks facilitate market access in global innovation systems? The case of offshore wind, Research Policy, 50(5), 104227. https://doi.org/10.10 16/j.respol.2021.104227

van Aswegen, M., \& Retief, F. P. (2020). The role of innovation and knowledge networks as a policy mechanism towards more resilient peripheral regions. Land Use Policy, 90, 104259. https://doi.org/10.1016/j.landusepol.2019.104259

Wang, C., Rodan, S., Fruin, M., \& Xu, X. (2014). Knowledge networks, collaboration networks, and exploratory innovation. Academy of Management Journal, 57(2), 459-514. https://doi.org/10.5465/amj.2011.0917

Wang, W., Sun, X. M., Cui, W. T., \& Chen, Y. G. (2019). The Impact of Knowledge Width and Depth on Internal Knowledge Search: The Regulatory Role of Structural Holes. Science \& Technology Progress and Policy, 36(23), $119-128$.

Xu, L.Y., Z., D. M., \& Chen, J. (2019). Analysis on the evolution of the characteristics of patent-based knowledge network structure: taking the Chinese automobile industry as an example. Journal of the China Society for Education, 38(07), $750-759$.

Yan, L., Hong, C. \& Cong, S. (2020). The impact of technological knowledge base network structure on enterprises becoming key developers--Based on the empirical analysis of China's electronic information industry, Research and Development Management, 32(04), 61-72.

Yao, Y. H., \& Li, Y. F. (2014). Research on the matching of enterprise innovation strategy and knowledge structure, Science of Science and Technology Management, 10, 150-158.

Yayavaram, S., \& Ahuja, G. (2008). Decomposability in Knowledge Structures and Its Impact on the Usefulness of Inventions and Knowledge-Base Malleability, Administrative Science Quarterly, 53(2), 333-362. https://doi.org/10.21 89/asqu.53.2.333 
Hao Jia-Jia, Li Chunling, Yuan Runsen, Khansa Pervaiz, Muhammad Asif Khan, Sun Xiaoran. Dual Innovation ...

Yayavaram, S., Srivastava, M. K., \& Sarkar, M. B. (2018). Role of search for domain knowledge and architectural knowledge in alliance partner selection. Strategic Management Journal, 39(8), 2277-2302. https://doi.org/10.10 02/smj.2791

Yi, Y., \& Junhui. H. (2017). Industry-University-Research Cooperation Network Small World, Knowledge Base and Enterprise Innovation, Science and Technology Management Research, 37(19), 139-146.

Zhan, X. D. (2019). Structural Capital and Technical Capability: The Role of External Knowledge Management and Knowledge Distance, Science \& Technology Progress and Policy, 36(02), 144-152.

Zibiao, L., Keyuan, S., \& Jingjing, Z. (2021). How does the enterprise knowledge base adjust the performance of multisource knowledge acquisition?-The threshold effect based on the depth and breadth of knowledge, Science Research, 39(02), 303-312.

\section{Biographies of Authors}

Hao Jia-Jia is a lecturer at the School of Economics and Management, Yanshan University (China), she achieved her $\mathrm{PhD}$ in Management Science and Engineering from Yanshan University (China), She has published with Sustainability, Computing \& Informatics, Intelligence Theory and Practice, International Journal of Security \& its Applications, Science \& Technology Progress an Policy, Information Technology Journal. Her research interest covers knowledge management and dual technology innovation.

Li Chunling is Professor at School of Economics and Management, Yanshan University (China); she achieved her PhD in Accounting from Renmin University of China. She has published with Energies, Sustainability, Science of Science and Management of S.\&T., Statistics \& Decision, her main field of interest is related to Corporate Governance, Financial Management and Technological Innovation.

Yuan Runsen is a PhD in Business Administration at School of Economics and Management, Yanshan University. She achieved her MSc degree in Accounting at the School of Economics and Management, Yanshan University. Her research interests focus on technology innovation, strategic management, capital market performance and mixed-ownership reform of SOEs. She has participated in a number of research projects related to technological innovation and published numerous academic papers in international and national journals and has accumulated rich professional experience in the fields of technological innovation, corporate strategy and China capital market.

Khansa Pervaiz is a PhD candidate in the Department of Business School and Management Sciences. She has been a researcher in the field of Finance. Her current research is concerned with Sovereign credit rating impact on financial markets. She is also a multi-disciplinary practitioner with experience banking finance, communication, and behavioral finance

Muhammad Asif Khan has earned his Doctoral in Finance from Huazhong University of Science and Technology, China. He is affiliated as Assistant Professor with the University of Kotli, Azad Jammu and Kashmir, Pakistan. Currently Dr. Khan is performing his duties as Chairman, Department of Commerce, and Director Students Financial Aid. He published with, Journal of Competitiveness, Mathematics, Amfiteatru Economic, Sustainability, Research in International Business and Finance, Energies, European Journal of International Management, Emerging Market Finance and Trade, Journal of Multinational Financial Management, Resources Policy, Applied Economics Letters, Comparative Economic Research, Montenegrin Journal of Economics, Sage Open, Economies, Chinese Economy, among others. Moreover, Dr. Khan is referee and part of Editorial Board of several WOS (SSCI, ESCI) journals. Dr. Khan's profile may be accessed here: RG: https://www.researchgate.net/profile/Muhammad-Khan-1182; Scholar: https://scholar.google.com/citations?user=48W_2oAAA $\mathrm{AJ} \& \mathrm{hl}=\mathrm{en}$

Sun Xiaoran is a student at the University of Leeds Business School (United Kingdom). Her major courses include Basic Accounting, Financial Accounting, Management Accounting, Corporate Finance, High-performance Finance, International Finance, Strategic Management, etc. Her research interests focus on dual technology innovation, strategic management. She has participated in a number of research projects related to technological innovation and published numerous academic papers.

The article has been reviewed. Received in April 2020; accepted in February 2022.

This article is an Open Access article distributed under the terms and conditions of the Creative Commons Attribution 4.0 (CC BY 4.0) License (http://creativecommons.org/licenses/by/4.0/). 